\title{
Matrix of Federal Statutes and Federal and State Court Decisions Reflecting the Core Concepts of Disability Policy
}

\author{
H. Rutherford Turnbull III, Brennan L. Wilcox, Matthew J. Stowe, and Gardner T. Umbarger III
}

\begin{abstract}
This article sets out the 18 core concepts of policy affecting families who have children with disabilities. It defines each concept, provides a reference to the constitutional principle(s) that undergird the core concept, cites the federal statutes that reflect the core concept, and references the decisions of the United States Supreme Court and other courts interpreting or defining the core concept.
\end{abstract}

As we explained in the previous article on the core concepts, our research methodology included an analysis of the federal statutes and selected cases related to these core concepts in the service-delivery sectors of education, child protective services and foster-and-adoption care, and public health and mental health. We report the results of that analysis here. A few words are in order, however, about the limitations and uses of the table that makes up the bulk of this article.

The table is limited in several respects. First, it includes only the federal statutes, not the regulations implementing each statute. For example, it includes the Americans with Dis abilities Act of 1990 (ADA) but not the socalled "integration" regulations, despite the fact that the U.S. Supreme Court relied on both, in Olmstead v. L. C., to hold that an unwarranted placement in an institutional or segregated facility violates ADA and its regulations.

Second, it includes only the federal statutes that are directly related to the three service-delivery strands. These strands interact with other service-delivery strands, such as housing, transportation, and employment. We exclude those strands, however, because of the limited scope of our present research.

Third, it includes decisions of the Court, other federal courts, and state appellate courts that interpret the applicable statute or advance the particular core concept. It does not include decisions that relate to other service-sector strands, even though those decisions may well be exactly on point with respect to the core concept. It also does not include all decisions related to the statute, only those that are from the Court or that have been precedent-setting.

A caveat is in order. It might seem that the core concepts are expressed only as legal concepts. In fact, the core concepts are grounded in the law and in other disciplines. The data that we reported in the previous article make that clear. Likewise, our article on the five models (this issue) demonstrates that a core legal concept is also a core concept in other disciplines and in nonlegal ways of approaching policy.

Given these limitations, what use can be made of the material provided here? First, it offers evidence of the existence of core concepts. The fact that so many statutes, precedent-setting decisions, or both, can be adduced is itself evidence that there is indeed a core concept.

Second, it was a useful device to provide direction for our research respondents in discussing the topic of core concepts. It stimulated their discussion; required them to focus on the three service-delivery sectors to the exclusion of other sectors; and enabled them to confirm, add to, or modify our preliminary list of core concepts and the statutes and cases that manifest them.

Third, it is a useful reference list. It also offers to the person who drafts legislation language that can be used in new or amended statutes (and interpretation of that language), and it connects the policy analyst to language that we use-and that the analyst can use-when applying our "tools" to the analysis of a policy document (see the article on tools in this issue).

Fourth, it provides a taxonomy for classifying new statutes and decisions. It can help the scholar or analyst make one kind of sense out of the ever-changing federal policy scene.

Fifth, it serves the same purpose if the scholar or analyst is concerned about state, rather than federal, law. There is no reason why the listing of core concepts at the federal level cannot be used for the same purpose at the state level; indeed, it can safely be assumed that state laws reflect the core concepts, because in many cases, state law must conform to federal law (either as a matter of the Supremacy Clause, compliance with the 14th Amendment to the U.S. Constitution, or compliance with Congress' spending power). 


\begin{tabular}{|c|c|c|c|c|}
\hline \multicolumn{5}{|c|}{ ANTIDISCRIMINATION } \\
\hline $\begin{array}{l}\text { Disability policy core } \\
\text { concepts }\end{array}$ & Constitutional principles & Federal statutory sources & $\begin{array}{c}\text { Federal case law related to } \\
\text { statutes }\end{array}$ & Other relevant case law \\
\hline $\begin{array}{l}\text { Antidiscrimination } \\
\text { (nondiscrimination and } \\
\text { antidiscrimination; equal } \\
\text { treatment, equal opportunity, } \\
\text { sometimes with } \\
\text { accommo dation; even-handed } \\
\text { treatment of similarly situated } \\
\text { individuals) } \\
\text { Under various statues generally } \\
\text { known as "civil rights acts," it is } \\
\text { illegal to discriminate against a } \\
\text { person with a disability solely by } \\
\text { reason of the person's disability. } \\
\text { One purpose of antidiscrimin- } \\
\text { ation is to ensure that decisions } \\
\text { about an individual are made } \\
\text { objectively and on the basis of } \\
\text { the whole person, including the } \\
\text { person's capabilities, } \\
\text { impairments, and preferences. A } \\
\text { more fundamental purpose } \\
\text { (more fundamental because } \\
\text { linked to the constitutional } \\
\text { doctrine of equal protection) is } \\
\text { to promote equal for people with } \\
\text { disabilities and even-handed } \\
\text { treatment of similarly situated } \\
\text { people (those with and without } \\
\text { disabilities). A principal method } \\
\text { to achieve antidiscrimination in } \\
\text { services is to provide reasonable } \\
\text { accommodations and } \\
\text { individualized and appropriate } \\
\text { services. }\end{array}$ & 5th and 14th Amendments & $\begin{array}{l} \\
\text { Americans with Disabilities Act } \\
\text { of } 1990 \text { (ADA), } 42 \text { U.S.C. } \S \S \\
\text { 12101 et seq.- prohibits dis - } \\
\text { crimination solely on the basis } \\
\text { of disability against an } \\
\text { otherwise qualified individual } \\
\text { who has a mental or physical } \\
\text { disability in the area of } \\
\text { employment, public services, } \\
\text { transportation, public } \\
\text { accommodations, and } \\
\text { telecommunications. }\end{array}$ & $\begin{array}{l}\text { Bowen } \boldsymbol{v} \text {. American Hospital } \\
\text { Association, } 476 \text { U.S. } 610 \\
\text { (1986) - Sec. } 504 \text { of the } \\
\text { Rehabilitation Act did not give } \\
\text { Secretary of Health and Human } \\
\text { Services authority to } \\
\text { commandeer state agencies. } \\
\text { Southeastern Community } \\
\text { College } \text { v. Davis, } 442 \text { U.S. } 397 \\
\text { (1987) - refusal of } \\
\text { educational institution to } \\
\text { admit individual with a hearing } \\
\text { disability to nursing program } \\
\text { did not violate Sec. } 504 \text { of the } \\
\text { Rehabilitation Act. } \\
\text { Board of Education } \text { v. } \text { Arline, } \\
480 \text { U.S. } 273 \text { (1987) - a } \\
\text { person afflicted with the } \\
\text { contagious disease of } \\
\text { tuberculosis may be a } \\
\text { "handicapped individual" } \\
\text { within the meaning of Sec. } 504 . \\
\text { Alexander } \boldsymbol{v} \text {. Choate, } 469 \text { U.S. } \\
\text { 287 (1985)-assuming that Sec. } \\
\text { 504 or its implementing } \\
\text { regulations reach some claims } \\
\text { of disparate-impact } \\
\text { discrimination, the effect of } \\
\text { Tennessee's reduction in annual } \\
\text { inpatient coverage is not } \\
\text { among them. } \\
\text { Pa. Dept. of Corrections } \boldsymbol{v} . \\
\text { Yeskey, } 524 \text { U.S. } 206 \text { (1998) - } \\
\text { state prisons are subject to the } \\
\text { ADA as they fall squarely within } \\
\text { Title II of the ADAs statutory } \\
\text { definition of "public entity." }\end{array}$ & $\begin{array}{l}\text { City of Cleburne v. Cleburne } \\
\text { Living Center, } 473 \text { U.S. } 432 \text { (1985) } \\
\text { - discrimination in community } \\
\text { placement violates equal } \\
\text { protection. } \\
\text { Olmstead v. L.C., } 527 \text { U.S. } 581 \\
\text { (1999) - unwarranted placement } \\
\text { in segregated facilities constitutes } \\
\text { discrimination that is prohibited by } \\
\text { the ADA. } \\
\text { Cleveland v. Policy Management } \\
\text { Systems Corp., } 526 \text { U.S. } 795 \text { (1999) } \\
\text { - a person may receive Social } \\
\text { Security Disability Insurance } \\
\text { benefits without necessarily losing } \\
\text { ADA protection. } \\
\text { Davis } \text { v. Monroe County Board of } \\
\text { Education, 526 U.S. 629(1999) - } \\
\text { local educational agency may be } \\
\text { liable for student-on-student trait } \\
\text { (sex) harassment. } \\
\text { Sutton v. United Air Lines, } 527 \\
\text { U.S. } 471 \text { (1999), Murphy } \boldsymbol{v} \text { United } \\
\text { Parcel Service, 527 U.S. 516 (1999), } \\
\text { and Albertson's } \boldsymbol{v} \text { Kirkingburg; } 527 \\
\text { U.S. 555 (1999) - the } \\
\text { determination whether an } \\
\text { individual is disabled, under the } \\
\text { ADA, should be made with } \\
\text { reference to measures that mitigate } \\
\text { the individual's impairment. }\end{array}$ \\
\hline
\end{tabular}


ANTIDISCRIMINATION

\begin{tabular}{|c|c|c|c|c|}
\hline Disability policy core concepts & Constitutional principles & $\begin{array}{c}\text { ANTIDISCRIMINATION } \\
\text { Federal statutory sources }\end{array}$ & $\begin{array}{l}\text { Federal case law related to } \\
\text { statutes }\end{array}$ & Other relevant case law \\
\hline & & $\begin{array}{l}\text { (k)-creates zero reject } \\
\text { (entitlement to education) } \\
\text { principle for students ages } 3 \text { - } \\
\text { 21 with disabilities. } \\
\text { Education Act of 1990 (IDEA), } \\
\text { 20 U.S.C. } § 1400 \text { et seq., } \\
\text { (k) }\end{array}$ & $\begin{array}{l}\text { Bragdon } \boldsymbol{v} \text {. Abbott, } 524 \text { U.S. } 624 \\
\text { (1998)-an individual with } \\
\text { HIV, even when not in } \\
\text { symptomatic phase, is a } \\
\text { qualified person with a } \\
\text { disability. } \\
\text { University of Alabama } \boldsymbol{v} \text {. } \\
\text { Garrett, } 531 \text { U.S. } 356 \text { (2001)- } \\
\text { the abrogation of state } \\
\text { immunity for money damages } \\
\text { under Title I of the ADA is } \\
\text { unconstitutional. } \\
\text { PGA Tour, Inc. } v \text {. Martin, } \\
\text { 121 S. Ct. } 1879 \text { (2001) (May } \\
\text { 29, 2001)-the PGA tour is a } \\
\text { "public accommodation" and } \\
\text { the operators of the tour } \\
\text { violate ADA's requirement of } \\
\text { reasonable accommodations } \\
\text { when, in insisting on the } \\
\text { "walking requirements" that } \\
\text { they } \\
\text { apply to all tour competitors, } \\
\text { they refuse to allow a } \\
\text { professional golfer with a } \\
\text { physical impairment to use a } \\
\text { golf cart while competing; } \\
\text { using the cart does not } \\
\text { fundamentally alter the nature } \\
\text { of the competition, the essence } \\
\text { of which is hitting the golf ball } \\
\text { into a hole with a golf club. } \\
\text { Honig v. Doe, } 484 \text { US. } 305 \\
\text { (1988)-school authorities may } \\
\text { not unilaterally exclude a child } \\
\text { with a disability from the class - } \\
\text { room during the pendency of } \\
\text { proceedings concerning the } \\
\text { child's education and dangerous } \\
\text { or dis ruptive conduct growing } \\
\text { out of the child's disabilities. }\end{array}$ & $\begin{array}{l}\text { FPPEEB v. College Savings Bank, } \\
527 \text { U.S. } 627 \text { (1999), College } \\
\text { Savings Bank v. FPPEEB, } 527 \text { U.S. } \\
666 \text { (1999), and Alden v. Maine, } \\
527 \text { U.S. } 706 \text { (1999)-federal reg- } \\
\text { ulation of activities for which state } \\
\text { may be sued in its own courts is } \\
\text { unconstitutional. } \\
\text { Kimel v. Board of Regents, } 528 \\
\text { U.S. } 62 \text { (2000)-the abrogation } \\
\text { of state immunity under the Age } \\
\text { Discrimination in Employment } \\
\text { Act (ADEA) is unconstitutional. }\end{array}$ \\
\hline
\end{tabular}


INDIVIDUALIZED AND APPROPRIATE SERVICES

\begin{tabular}{|c|c|c|c|c|}
\hline Disability policy core concepts & Constitutional principles & Federal statutory sources & $\begin{array}{l}\text { Federal case law related to } \\
\text { statutes }\end{array}$ & Other relevant case law \\
\hline $\begin{array}{l}\text { Individualized and } \\
\text { Appropriate Services } \\
\text { These services are specially } \\
\text { tailored to meet the needs and } \\
\text { choices of persons with } \\
\text { disabilities and their families. } \\
\text { Examples are individualized } \\
\text { education, rehabilitation, } \\
\text { habilitation, treatment, and } \\
\text { family-support plans. A } \\
\text { synonym for individualized and } \\
\text { appropriate services is genuine, } \\
\text { effective, and meaningful services. } \\
\text { Principal methods to achieve } \\
\text { individualized and appropriate } \\
\text { services include the core concepts } \\
\text { of classification, capacity-based } \\
\text { services, empowerment and } \\
\text { participatory decision-making, } \\
\text { and service coordination and } \\
\text { collaboration. Under } \\
\text { antidiscrimination (also a core } \\
\text { concept), reasonable } \\
\text { accommodations or other } \\
\text { modifications to services, } \\
\text { policies, practices, and procedures } \\
\text { are required unless they } \\
\text { fundamentally alter the nature of } \\
\text { the particular service or program } \\
\text { or result in an undue hardship to } \\
\text { a service or program. Physical } \\
\text { and technological } \\
\text { (communication) accessibility are } \\
\text { aspects of individualized and } \\
\text { appropriate services. }\end{array}$ & $\begin{array}{l}\text { The substantive due process } \\
\text { doctrine protects a person from } \\
\text { government action that is } \\
\text { adverse to a person's life, } \\
\text { liberty, or property. As a limit } \\
\text { on what government may do, it } \\
\text { requires individualized } \\
\text { decision-making and thus is } \\
\text { relevant to the core concept of } \\
\text { individualized and appropriate } \\
\text { services; specially designed } \\
\text { interventions to maintain or } \\
\text { improve the capacity of the } \\
\text { particular individual, consistent } \\
\text { with the substantive due } \\
\text { process and equal protection } \\
\text { clauses of the 5th and 14th } \\
\text { Amendments. }\end{array}$ & $\begin{array}{l} \\
\text { ADA, } 42 \text { U.S.C. } \$ \S 12101 \text { et seq. } \\
\text { and Rehabilitation Act (Sec. } \\
\text { 504), } 29 \text { U.S.C. } \$ 794- \\
\text { requires individualized, } \\
\text { reasonable accommodations for } \\
\text { nondiscrimination. } \\
\text { Children's and Communities } \\
\text { Mental Health Systems } \\
\text { Improvement Act, } 42 \text { U.S.C. } \S \S \\
\text { 290ff et seq.- requires an } \\
\text { individualized plan for services; } \\
\text { expands the range of services } \\
\text { available to children and their } \\
\text { families; improves funding to } \\
\text { other service providers involved } \\
\text { with the child; provides for case } \\
\text { management and periodic } \\
\text { assessment toward individual } \\
\text { goals; requires multidisciplinary } \\
\text { coordination among education, } \\
\text { health-care, vocational, and } \\
\text { social services agencies; seeks to } \\
\text { ensure that children and families } \\
\text { receive appropriate services. }\end{array}$ & $\begin{array}{l}\text { Board of Education v. Rowley, } \\
458 \text { U.S. 176 (1982)-the } \\
\text { definition of "appropriate } \\
\text { education" includes individual } \\
\text { benefit. } \\
\text { Irving Independent School } \\
\text { District } \boldsymbol{v} \text {. Tatro, } 468 \text { U.S. } 883 \\
\text { (1984)-IDEA and related } \\
\text { services that assist in education } \\
\text { and health maintenance include } \\
\text { clean, intermittent } \\
\text { catheterization. } \\
\text { Cedar Rapids Community } \\
\text { School Dist. } \boldsymbol{v} \text {. Garret } \boldsymbol{F} ., 526 \\
\text { U.S.66(1999)-IDEA required } \\
\text { provision of the related service } \\
\text { of a full-time nurse (not a } \\
\text { medical service). }\end{array}$ & $\begin{array}{l}\text { Wyatt } \text {. Stickney, } 325 \text { E Supp. } \\
781 \text { (M.D. Ala. 1971)-to deprive } \\
\text { any citizen of his or her liberty } \\
\text { upon the altruistic theory that the } \\
\text { confinement is for humane, } \\
\text { therapeutic reasons and then fail to } \\
\text { provide adequate treatment violates } \\
\text { the very fundamentals of due } \\
\text { process. } \\
\text { Youngberg } v \text {. Romeo, } 457 \text { U.S. } 307 \\
\text { (1982)-an involuntarily } \\
\text { committed person with retardation } \\
\text { has due process liberty interests } \\
\text { requiring the state to provide } \\
\text { minimally adequate training to } \\
\text { ensure safety and freedom from } \\
\text { undue restraint. }\end{array}$ \\
\hline
\end{tabular}


INDIVIDUALIZED AND APPROPRIATE SERVICES

\begin{tabular}{|c|c|c|c|c|}
\hline $\begin{array}{c}\begin{array}{c}\text { Disability policy core } \\
\text { concepts }\end{array} \\
\end{array}$ & Constitutional principles & Federal statutory sources & $\begin{array}{c}\begin{array}{c}\text { Federal case law related to } \\
\text { statutes }\end{array} \\
\end{array}$ & Other relevant case law \\
\hline & & $\begin{array}{l}\text { Child Health Act, } 42 \text { U.S.C. } \\
\S \S 290 \text { bb-39 et seq.-provides } \\
\text { for integrated treatment for } \\
\text { children with co-occurring } \\
\text { disorders (dual diagnoses). } \\
\text { Early Periodic Screening, } \\
\text { Detection and Treatment } \\
\text { (EPSDT) (1998) } 42 \text { U.S.C. } \S \S \\
\text { 1396 et seq.- provides for the } \\
\text { periodic evaluations, diagnoses, } \\
\text { treatments, and other measures } \\
\text { required under the medical } \\
\text { assistance program to correct or } \\
\text { ameliorate defects, physical and } \\
\text { mental illnesses, and conditions } \\
\text { discovered by the screening } \\
\text { process. Services must be } \\
\text { sufficient in scope and duration } \\
\text { to treat the condition. } \\
\text { Promoting Safe and Stable } \\
\text { Families Program (1997), } 42 \\
\text { U.S.C. } \S \S 629 \text { et seq.- helps } \\
\text { states develop and expand } \\
\text { family support and family } \\
\text { preservation service programs. } \\
\text { See also Adoption Assistance } \\
\text { and Child Welfare Act, as } \\
\text { amended (see statutes listed } \\
\text { under Protection From Harm } \\
\text { and under Family Integrity and } \\
\text { Unity), } 42 \text { U.S.C. } \S \S 620 \text { et seq. } \\
\text { (child welfare services), } \S 670 e \\
\text { seq., and } \S 1396 \text { a and } \S 1396 d \\
\text { (foster care and adoption } \\
\text { assistance). } \\
\text { Rehabilitation Act, } 29 \text { U.S.C. } \S \\
\text { 722-provides for vocational } \\
\text { rehabilitation services and covers } \\
\text { eligibility and individualized } \\
\text { plan for employment. }\end{array}$ & & \\
\hline
\end{tabular}


INDIVIDUALIZED AND APPROPRIATE SERVICES

\begin{tabular}{|c|c|c|c|c|}
\hline $\begin{array}{c}\begin{array}{c}\text { Disability policy core } \\
\text { concents }\end{array} \\
\end{array}$ & Constitutional principles & Federal statutory sources & $\begin{array}{c}\begin{array}{c}\text { Federal case law related to } \\
\text { statutes }\end{array} \\
\end{array}$ & Other relevant case law \\
\hline & & $\begin{array}{l}\text { Omnibus Budget } \\
\text { Reconciliation Act of } 1987, \\
\text { P.L. 100-203- establishes } \\
\text { program requiring individualized } \\
\text { decision-making related to } \\
\text { nursing home placement and } \\
\text { out-placement of persons with } \\
\text { mental disabilities. } \\
\text { Developmental Disabilities } \\
\text { Assistance \& Bill of Rights } \\
\text { Act, } 42 \text { U.S.C. } \$ \text { } 15001 \text { et } \\
\text { seq.- ensures that individuals } \\
\text { with dis abilities will participate } \\
\text { in the design of and access to } \\
\text { culturally competent services, } \\
\text { supports, and other assistance. }\end{array}$ & & \\
\hline
\end{tabular}


CLASSIFICATION

\begin{tabular}{|c|c|c|c|c|}
\hline Disability policy core concepts & Constitutional principles & Federal statutory sources & $\begin{array}{c}\begin{array}{c}\text { Federal case law related to } \\
\text { statutes }\end{array} \\
\end{array}$ & Other relevant case law \\
\hline
\end{tabular}


CLASSIFICATION

\begin{tabular}{|c|c|c|c|c|}
\hline Disability policy core concepts & Constitutional principl es & Federal statutory sources & $\begin{array}{c}\text { Federal case law related to } \\
\text { statutes }\end{array}$ & Other relevant case law \\
\hline & & $\begin{array}{l}\text { End Stage Renal Disease } \\
\text { program, } 42 \text { U.S.C. } \$ 1395 \mathrm{rr}- \\
\text { creates entitlement to medical } \\
\text { care funding using an existing } \\
\text { program that serves a similar } \\
\text { group of beneficiaries with } \\
\text { chronic health-care needs who } \\
\text { otherwise might not receive } \\
\text { care. } \\
\text { IDEA,20U.S.C. } \$ 1414(\mathrm{a})(\mathrm{b})(\mathrm{c}) \\
\text { requires nondiscriminatory } \\
\text { evaluations to determine } \\
\text { whether child has a disability } \\
\text { and if so, the child's educational } \\
\text { needs. }\end{array}$ & & \\
\hline
\end{tabular}


CAPACITY BASED SERVICES

\begin{tabular}{|c|c|c|c|c|}
\hline Disability policy core concepts & Constitutional principles & Federal statutory sources & \begin{tabular}{|c|}
$\begin{array}{c}\text { Federal case law related to } \\
\text { statutes }\end{array}$ \\
\end{tabular} & Other relevant case law \\
\hline $\begin{array}{l}\text { Capacity-Based Services } \\
\text { Evaluate the unique strengths } \\
\text { and needs of a person with a } \\
\text { disability or the person's family. } \\
\text { They include a person- or } \\
\text { family-directed evaluation of the } \\
\text { choices (autonomy), resources, } \\
\text { priorities, and concerns and also } \\
\text { the identification of services } \\
\text { necessary to enhance family and } \\
\text { individual capacity. The term } \\
\text { reflects the "strengths" } \\
\text { perspective and rejects the } \\
\text { "pathology" perspective. }\end{array}$ & & $\begin{array}{l}\text { IDEA, } 20 \text { U.S.C. } \S 1414(d)(1)(\text { A) } \\
\text { provides for IEP to address student' } \\
\text { capacity (or lack of it) to participate } \\
\text { in the general curriculum; } \S 1436 \\
\text { (a)(1) and (2)provides for an IFSP } \\
\text { that builds on capacity of person } \\
\text { with disability and their family. } \\
\text { Rehabilitation Act, } 29 \text { U.S.C. } \S \S \\
701 \text { et seq.- authorizes funding } \\
\text { for rehabilitation services. } \\
\text { Children's and Communities } \\
\text { Mental Health Systems } \\
\text { Improvement Act, } 42 \text { U.S.C. } \S \S \\
290 f f \text { et seq.- provides for } \\
\text { multidisciplinary assessment and } \\
\text { coordination of child and family } \\
\text { needs; provides services that } \\
\text { enhance family cohesiveness and } \\
\text { requires consideration of family } \\
\text { service needs along with those of } \\
\text { the child; plans are to be designed } \\
\text { and carried out with the } \\
\text { participation of the child and } \\
\text { family. } \\
\text { EPSDT, } 42 \text { U.S.C. } \S \S 1396 \text { et seq.- } \\
\text { requires that services be provided } \\
\text { on the basis of child's individual } \\
\text { needs as a result of assessments of } \\
\text { strengths and needs of the child. } \\
\text { Adoption Assistance and } \\
\text { Child Welfare Act, P.L. } 96-272 \text {, } \\
42 \text { U.S.C. } \S 620 \text { et seq. (child } \\
\text { welfare services) \& } \S \S 670 \text { et seq. } \\
\text { (foster care and adoption } \\
\text { assis tance), as amended by } \\
\text { Adoption and Safe Families Act, P } \\
\text { L. } 105-89,42 \text { U.S.C. } \S \S 629 \text { et seq. } \\
\text { helps states develop and expand } \\
\text { family support and family } \\
\text { preservation service programs. }\end{array}$ & & \\
\hline
\end{tabular}


EMPOWERMENT/PARTICIPATORY DECISION-MAKING

\begin{tabular}{|c|c|c|c|c|}
\hline$\overline{\text { Disability policy core concepts }}$ & Constitutional principles & $\begin{array}{l}\begin{array}{l}\text { Federal statutory } \\
\text { sources }\end{array} \\
\end{array}$ & $\begin{array}{c}\begin{array}{c}\text { Federal case law related to } \\
\text { statutes }\end{array} \\
\end{array}$ & Other relevant case law \\
\hline $\begin{array}{l}\text { Empowerment/Participatory } \\
\text { Decision-Making } \\
\text { Involves the means by which a } \\
\text { person or family-or a duly } \\
\text { appointed surrogate-secures } \\
\text { what they want from a service- } \\
\text { provider system; the means is } \\
\text { through the person or family's } \\
\text { participation with the system in } \\
\text { consenting (see autonomy) or } \\
\text { otherwise participating in the } \\
\text { decision-making processes by } \\
\text { which the services that they will } \\
\text { receive are planned, developed, } \\
\text { implemented, and evaluated. The } \\
\text { concept applies to decisions at } \\
\text { the macro/system level and to } \\
\text { decisions at the micro/individual } \\
\text { level. }\end{array}$ & $\begin{array}{l}\text { These parallel the concept and } \\
\text { principles of autonomy. }\end{array}$ & $\begin{array}{l}\text { IDEA, } 20 \text { U.S.C. } \S 1412 \\
\text { (establishes free and } \\
\text { appropriate public education } \\
\text { [FAPE] eligibility standards); } \S \\
1414 \text { (explains requirements for } \\
\text { evaluations, IEPs, placements, } \\
\text { parent and student } \\
\text { participation, self- } \\
\text { determination in transition); } \S \\
\text { 1415 (establishes procedural } \\
\text { safeguards); and } \S 1431 \text { et } \\
\text { seq. (Part C-s ets out } \\
\text { provisions for infants and } \\
\text { toddlers). } \\
\text { Developmental Disabilities } \\
\text { Assistance \& Bill of Rights } \\
\text { Act,42 U.S.C. } \S \S 15001 \text { et } \\
\text { seq. creates a "bill of rights" } \\
\text { for persons with developmental } \\
\text { disabilities, funds services for } \\
\text { persons with developmental } \\
\text { disabilities, has funding } \\
\text { authority for university- } \\
\text { affiliated facilities, and } \\
\text { establishes a system of } \\
\text { protection and advocacy } \\
\text { organizations in each state. }\end{array}$ & & \\
\hline
\end{tabular}


SERVICE COORDINATION AND COLLABORATION

\begin{tabular}{|c|c|c|c|c|}
\hline $\begin{array}{c}\begin{array}{c}\text { Disability policy core } \\
\text { concepts }\end{array} \\
\end{array}$ & Constitutional principles & Federal statutory sources & $\begin{array}{c}\begin{array}{c}\text { Federal case law related to } \\
\text { statutes }\end{array} \\
\end{array}$ & Other relevant case law \\
\hline $\begin{array}{l}\text { Service Coordination and } \\
\text { Collaboration } \\
\text { These activities assist individuals } \\
\text { with disabilities or their families to } \\
\text { access and benefit from services } \\
\text { from more than one provider } \\
\text { system (interagency) or within a } \\
\text { single provider system (intra- } \\
\text { agency). }\end{array}$ & & $\begin{array}{l}\text { IDEA, } 20 \text { U.S.C. } \S \S 1431 \text { et } \\
\text { seq. (Part C)-provides for a } \\
\text { state-wide system of services } \\
\text { to families of infants and } \\
\text { toddlers; } 20 \text { U.S.C. } \$ 1414 \\
\text { (d)(1)(A)(vii)- provides for } \\
\text { interagency roles in transition } \\
\text { planning; } 20 \text { U.S.C. } \S 1412 \\
\text { (a)(12)-provides for } \\
\text { interagency agreements } \\
\text { (especially related to state } \\
\text { Medicaid agency). } \\
\text { Assistive Technology Actof } \\
\text { 1998,29 U.S.C. §§ 1301 et } \\
\text { seq.- establishes federal } \\
\text { funding to help develop } \\
\text { consumer-driven, statewide } \\
\text { service-delivery systems that } \\
\text { increase access to assistive } \\
\text { technology devices and services } \\
\text { to individuals of all ages with } \\
\text { disabilities. } \\
\text { Children's and Communities } \\
\text { Mental Health Systems } \\
\text { Improvement Act, } 42 \text { U.S.C. } \S \S \\
\text { 290ff } \text { et seq.--authorizes grants } \\
\text { to public and private agencies } \\
\text { for the purpose of providing } \\
\text { comprehensive, individualized, } \\
\text { community-based mental health } \\
\text { services to children with serious } \\
\text { emotional disturbance and their } \\
\text { families; is the basis for wrap- } \\
\text { around services. } \\
\text { Child Health Act, } 42 \text { U.S.C. } \S \S \\
\text { 290bb-39 et seq.-requires } \\
\text { interagency response to } \\
\text { children with co-occurring } \\
\text { disorders (dual diagnoses). }\end{array}$ & & $\begin{array}{l}\text { R.C.v. Nachman, } 969 \text { E Supp. } \\
682 \text { (M.D. Ala. 1997)-resulted } \\
\text { in a consent decree establishing a } \\
\text { comprehensive array of services } \\
\text { for children in foster care based } \\
\text { on an established set of goals and } \\
\text { objectives. }\end{array}$ \\
\hline
\end{tabular}


PROTECTION FROM HARM

\begin{tabular}{l|}
\hline Disability policy core concepts \\
\hline ProtectionFromHarm \\
A person has the right to be free \\
from harm while in state \\
custody or in the care of such \\
private individuals as family \\
members or other caregivers.
\end{tabular}

\section{Constitutional principles \\ Protections of the 4th and 8th Amendments (unreasonable} seizure; cruel and unusual

punishment); also 1st, 5th, and 14th Amendments (substantive due process)

Federal statutory sources

\section{Adoption Assistance and} Child Welfare Act of 1980 (PL.

96-272), as amended by the

Personal Responsibility and

Work Opportunity

Reconciliation Act of 1996

(a.k.a. Child Care and

Development Block Grant

Amendments of 1996) (PL.

104-193), Adoption and Safe

Families Act of 1997

(PL. 105-89), Child Support

Performance and Incentive

Act of 1998(PL. 105-200), and

Foster Care Independence

Act of 1999-as codified in 42

U.S.C. $\S \S 620$ et seq., $\S \S 629$,

670 et seq., and $\S \S 1396 a$ and

1396d-establish grants to state

to operate family preservation,

family reunification, and foster-

care and adoption systems;

create rebuttable presump tion in

favor of preservation and

reunification ("reasonable

efforts"); create exceptions to

requirement of reasonable

efforts; expedite permanency

plans; and prevent foster-care

drift.

Child Health Act, 42 U.S.C. $\S \S$

290ii et seq.-places limits on

the use of seclusion and

restraints.

\section{Child Abuse Preventionand}

Enforcement Act (2000), 42

U.S.C $\$ 14601$ (b) et seq.-

strengthens criminal

background checks and law

\begin{tabular}{|c|c}
\hline $\begin{array}{c}\text { Federal case law related to } \\
\text { statutes }\end{array}$ & Other relevant case law \\
\hline & $\begin{array}{l}\text { Youngberg } \text { v. Romeo, 457 U.S. } 307 \\
(1982)-\text { an involuntarily }\end{array}$
\end{tabular}

(1982)-an involuntarily

committed person with retardation

has due process liberty interests

requiring the state to provide

minimally adequate training to

ensure safety and freedom from

undue restraint.

DeShaney v. Winnebago, 489

U.S. 189 (1982) § 1983 (civil

rights violation)-liability does

not attach in absence of physical

custody by state.

Wyatt v. Stickney, 325 F. Supp. 781(M.D. Ala. 1971)-to deprive any citizen of his or her liberty upon the altruistic theory that the confinement is for humane,

therapeutic reasons and then fail

to provide adequate treatment

violates the very fundamentals of due process.

Franklin v. Gwinett, 503 U.S. 60 (1992), and Davis v. Monroe, 526 U.S. 629 (1999)-school is liable

in damages when it is deliberately indifferent to known acts of sexual harassment that were so severe,

pervasive, and objectively offensive that they barred a student's access to educational opportunity, whether the acts were those of faculty and staff or of other students. 
PROTECTION FROM HARM

\begin{tabular}{|c|c|c|c|c|}
\hline Disability policy core concepts & Constitutional principles & Federal statutory sources & $\begin{array}{c}\text { Federal case law related to } \\
\text { statutes }\end{array}$ & Other relevant case law \\
\hline & & $\begin{array}{l}\text { enforcement capacities of state } \\
\text { and local government; Child } \\
\text { Abuse Prevention and } \\
\text { Treatment Act }(1988 \text {, as } \\
\text { amended), } 42 \text { U.S.C. } \$ 5101 \text {, } \\
\text { with regulations at } 45 \text { C.F.R. } \\
\text { Part } 84 \S 84.55 \text {-creates } \\
\text { presumption in favor of medical } \\
\text { treatment of newborns with } \\
\text { dis abilities but allows } \\
\text { presumptions to be rebutted for } \\
\text { any of three reasons. } \\
\text { IDEA, 20 U.S.C. } \S 1414 \\
\text { (d)(3)(B)(i)-requires special } \\
\text { consideration of use of positive } \\
\text { behavioral supports; } \S 1415 \\
\text { (k)(1)(B)-requires functional } \\
\text { behavioral assessment and } \\
\text { behavioral intervention plan. }\end{array}$ & & \\
\hline
\end{tabular}


LIBERTY

\begin{tabular}{|c|c|c|c|c|}
\hline Disability policy core concepts & Constitutional principles & Federal statutory sources & $\begin{array}{c}\begin{array}{c}\text { Federal case law related to } \\
\text { statutes }\end{array} \\
\end{array}$ & Other relevant case law \\
\hline $\begin{array}{l}\text { Liberty } \\
\text { A person has the right to be free } \\
\text { from unwarranted physical or } \\
\text { other confinement by a } \\
\text { government. Related to it is a } \\
\text { claim to be treated with respect } \\
\text { and dignity. Sometimes the } \\
\text { concept of liberty is associated } \\
\text { with the concept of autonomy. } \\
\text { Also associated with the core } \\
\text { concept of liberty is the core } \\
\text { concept of integration: A } \\
\text { person cannot experience } \\
\text { integration unless he or she also } \\
\text { experiences liberty. }\end{array}$ & $\begin{array}{l}\text { 1st, } 5 \text { th, and } 14 \text { th Amendments } \\
\text { (substantive due process) }\end{array}$ & $\begin{array}{l}\text { Developmental Disabilities } \\
\text { Assistance \& Bill of Rights } \\
\text { Act, } 42 \text { U.S.C. } \S \S 15001 \text { et } \\
\text { seq.- creates a "bill of rights" } \\
\text { for persons with } \\
\text { developmental disabilities, } \\
\text { funds services for persons } \\
\text { with developmental } \\
\text { disabilities, has funding } \\
\text { authority for university- } \\
\text { affiliated facilities, and } \\
\text { establishes a system of } \\
\text { protection and advocacy } \\
\text { organizations in each state. } \\
\text { Children and Communities } \\
\text { Mental Health Systems } \\
\text { Improvement Act of } 1994,42 \\
\text { U.S.C. } \S 290 f f \text { et seq.- } \\
\text { expands outpatient treatment } \\
\text { settings, provides for intensive } \\
\text { home-based services for } \\
\text { children at risk of out-of-home } \\
\text { placement, expands the } \\
\text { availability of therapeutic } \\
\text { services in settings with fewer } \\
\text { than } 10 \text { children, seeks to ensure } \\
\text { services are delivered in the } \\
\text { least restrictive and most } \\
\text { normative setting possible, and } \\
\text { removes incentives to fund } \\
\text { room and board at inpatient } \\
\text { hospital settings. } \\
\text { IDEA, } 20 \text { U.S.C. } \S \S 1414(d) \\
\text { and } 1415(k)-\text { requires } \\
\text { consideration of positive } \\
\text { behavioral interventions, } \\
\text { strategies, and supports in } \\
\text { IEPs and in relation to } \\
\text { discipline. }\end{array}$ & $\begin{array}{l}\text { Pennhurst State School \& } \\
\text { Hospital v. Halderman } \\
\text { (Pennhurst I), 451 U.S. } 1 \\
\text { (1981), and Pennhurst State } \\
\text { Sch. \& Hosp. v. Halderman } \\
\text { (Pennhurst II), 465U.S.89 } \\
\text { (1984)-the Developmental } \\
\text { Dis abilities Act does not create } \\
\text { for persons with mental } \\
\text { retardation any substantive } \\
\text { rights, including treatment, } \\
\text { services, habilitation, and the } \\
\text { provision of those services in the } \\
\text { least restrictive setting. }\end{array}$ & $\begin{array}{l}\text { Wyatt } \text { v. Stickney, } 325 \text { F. Supp. } \\
781 \text { (M.D. Ala. 1971)-to } \\
\text { deprive any citizen of his or her } \\
\text { liberty upon the altruistic theory } \\
\text { that the confinement is for } \\
\text { humane, therapeutic reasons and } \\
\text { then fail to provide adequate } \\
\text { treatment violates the very } \\
\text { fundamentals of due process. } \\
\text { O'Connor } v \text {. Donaldson, } 422 \text { U.S. } \\
\text { 563 (1974)-a state may not } \\
\text { constitutionally confine in a } \\
\text { mental hospital a nondangerous } \\
\text { individual who is capable of } \\
\text { surviving safely in freedom by } \\
\text { himself or with the help of willing } \\
\text { and responsible family members } \\
\text { or friends. } \\
\text { Youngberg } v \text {. Romeo, } 457 \text { U.S. } 307 \\
\text { (1982)-an involuntarily } \\
\text { committed person with retardation } \\
\text { has due process liberty interests } \\
\text { requiring the state to provide } \\
\text { minimally adequate training to } \\
\text { ensure safety and freedom from } \\
\text { undue restraint. } \\
\text { Durflinger } v . \text { Artiles, } 234 \text { Kan. } 484 \\
\text { has (1983)-a physician has a } \\
\text { duty to use reasonable and } \\
\text { ordinary care and discretion when } \\
\text { recommending that a committed } \\
\text { patient be discharged; this duty is } \\
\text { owed to the patient and the public. }\end{array}$ \\
\hline
\end{tabular}


LIBERTY

\begin{tabular}{|c|c|c|c|c|}
\hline $\begin{array}{c}\text { Disability policy core } \\
\text { concents }\end{array}$ & Constitutional principles & Federal statutory sources & $\begin{array}{c}\text { Federal case law related to } \\
\text { statutes }\end{array}$ & Other relevant case law \\
\hline & & $\begin{array}{l}\text { Child Health Act of 2000,42 } \\
\text { U.S.C. § 290ii-places limits } \\
\text { on use of seclusion and } \\
\text { restraints. }\end{array}$ & & $\begin{array}{l}\text { Beckv. KU Psychiatry } \\
\text { Foundation, } 580 \text { F Supp. } 527 \text { (D. } \\
\text { Kan. 1984)-one who takes charge } \\
\text { of a person whom he knows or } \\
\text { should know to be likely to cause } \\
\text { bodily harm to others if not } \\
\text { controlled is under a duty to } \\
\text { exercise reasonable care to control } \\
\text { the person to pre vent him from } \\
\text { doing such harm. } \\
\text { Washington v. Harper, } 494 \text { U.S. } \\
210 \text { (1990)-the Washington state } \\
\text { policy that allowed prison } \\
\text { authorities to administer } \\
\text { medication to inmates against their } \\
\text { will was constitutional because the } \\
\text { procedures did not deprive } \\
\text { respondent of the right to refuse } \\
\text { treatment without adequate due } \\
\text { process. } \\
\text { Riggins } v \text {. Nevada, } 504 \text { U.S. } 127 \\
\text { (1992)-the court identifies } \\
\text { standards sufficient to justify } \\
\text { forced administration of the drug } \\
\text { to the defendant during his trial. } \\
\text { Kansas } v \text {. Hendricks, } 521 \text { U.S. } 346 \\
\text { (1997)-a state law providing } \\
\text { standards and procedures for civil } \\
\text { commitment of sexually violent } \\
\text { predators sufficiently satisfies } \\
\text { substantive due process } \\
\text { requirements and does not violate } \\
\text { the federal Constitution's double } \\
\text { jeopardy or ex post facto clauses. }\end{array}$ \\
\hline
\end{tabular}


AUTONOMY

\begin{tabular}{|c|c|c|c|c|}
\hline Disability policy core concepts & Constitutional principles & Federal statutory sources & $\begin{array}{c}\text { Federal case law related to } \\
\text { statutes }\end{array}$ & Other relevant case law \\
\hline $\begin{array}{l}\text { Autonomy } \\
\text { Refers to the right of a person } \\
\text { with a disability or the person's } \\
\text { family to consent, refuse to } \\
\text { consent, withdraw consent, or } \\
\text { otherwise control or exercise } \\
\text { choice or control over what } \\
\text { happens to him or her. If the } \\
\text { person or family is legally } \\
\text { incompetent to exercise this } \\
\text { right, a duly appointed } \\
\text { surrogate may do so. Sometimes } \\
\text { the concept of autonomy is } \\
\text { expressed as "independence" or } \\
\text { "self-determination." One form } \\
\text { of independence is independent } \\
\text { living. Independence and } \\
\text { independent living may refer to } \\
\text { the ability to act by one's self, } \\
\text { relatively unassisted. Associated } \\
\text { with the concept of autonomy is } \\
\text { privacy and confidentiality, }\end{array}$ & $\begin{array}{l}\text { Autonomy, choice, consent, } \\
\text { privacy, and liberty as } \\
\text { grounded in the } 1 \text { st and } 14 \text { th } \\
\text { Amendments }\end{array}$ & $\begin{array}{l}\text { Developmental Disabilities } \\
\text { Assistance \& Bill of Rights Act } \\
\text { of } 2000,42 \text { U.S.C. } \S \S 15001 \text { et } \\
\text { seq.-creates a "bill of rights" } \\
\text { for persons with developmental } \\
\text { disabilities, establishes state } \\
\text { developmental disabilities } \\
\text { planning councils, funds } \\
\text { services for persons with } \\
\text { developmental dis abilities, has } \\
\text { funding authority for university- } \\
\text { affiliated facilities, and } \\
\text { establishes a system of } \\
\text { protection and advocacy } \\
\text { organizations in each state. } \\
\text { Rehabilitation Act, } 29 \text { U.S.C. } \\
\S \S 701 \text { et seq.-authorizes } \\
\text { federal funding for } \\
\text { individualized vocational } \\
\text { rehabilitation service provision, } \\
\text { including supported } \\
\text { employment, independent } \\
\text { living centers, and independent } \\
\text { living. } \\
\text { IDEA, } 20 \text { U.S.C. } \S 1400(d)- \\
\text { explains that the purpose of } \\
\text { special education includes } \\
\text { preparation to lead independent } \\
\text { adult lives; } \S 1414(d)(1)(A)(\text { vii) } \\
\text { provides for student } \\
\text { participation in postsecondary } \\
\text { planning. }\end{array}$ & & $\begin{array}{l}\text { Natanson } \text { v. Kline, } 186 \text { Kan. } \\
\text { 393, Reh'g den., } 187 \text { Kan. } 186 \\
\text { (1960)- a physician violates his } \\
\text { duty to his patient and subjects } \\
\text { himself to liability for } \\
\text { malpractice if he makes no } \\
\text { disclosure of significant facts } \\
\text { within his knowledge that are } \\
\text { necessary to form the basis of an } \\
\text { intelligent consent by the patient } \\
\text { to proposed treatment. } \\
\text { Canterbury } v \text {. Spence, } 464 \text { F.2d } \\
772 \text { (1972)-provider/physician } \\
\text { disclosure must be guided by } \\
\text { what a reasonably prudent } \\
\text { patient would want to know. } \\
\text { Strunk } v \text {. Strunk, } 445 \text { S.W. } 2 d \\
\text { 145 (1969)-the courts have } \\
\text { sufficient power to employ } \\
\text { substituted judgment and give } \\
\text { consent for an incompetent } \\
\text { individual to undergo a medical } \\
\text { procedure if the operation is } \\
\text { deemed to be in the individual's } \\
\text { best interest. } \\
\text { Superintendent } v \text {. Saikwicz, } \\
\text { 373 Mass. } 728 \text { (1977)-both the } \\
\text { doctrine of informed consent } \\
\text { and the constitutional right of } \\
\text { privacy protect the right of a } \\
\text { patient to refuse medical } \\
\text { treatment in appropriate } \\
\text { circumstances; in the case of an } \\
\text { incompetent patient, the right } \\
\text { may be asserted by a guardian. }\end{array}$ \\
\hline
\end{tabular}




\begin{tabular}{|c|c|c|c|c|}
\hline Disability policy coreconcepts & Constitutional principles & Federal statutory sources & $\begin{array}{c}\begin{array}{c}\text { Federal case law related to } \\
\text { statutes }\end{array} \\
\end{array}$ & other relevant case law \\
\hline & & & & $\begin{array}{l}\text { Inre: Lee Ann Grady, } 170 \text { N.J. } \\
\text { Super. } 98, \text { vacated by } 85 \text { N.J. } 235 \\
\text { (1981) - parents of a legally } \\
\text { incompetent woman in their role } \\
\text { as their daughter's guardians must } \\
\text { be permitted to exercise their } \\
\text { substituted judgment for their } \\
\text { daughter on the subject of } \\
\text { sterilization. } \\
\text { Cruzan v. Director, Missouri Dept. } \\
\text { of Health, } 497 \text { U.S. } 261 \text { (1990)-a } \\
\text { state may require a decision on } \\
\text { withholding life-maintaining } \\
\text { services to be protected by proof, } \\
\text { at a clear and convincing level, } \\
\text { that the decision is consistent with } \\
\text { the wishes/consent of the } \\
\text { person/patient. } \\
\text { Heller v. Doe, } 509 \text { U.S. } 312 \\
\text { (1993)-allowing participation by } \\
\text { guardians and immediate family } \\
\text { members in commitment } \\
\text { proceedings does not violate the } \\
\text { 14th Amendment's due process } \\
\text { clause. }\end{array}$ \\
\hline
\end{tabular}




\begin{tabular}{|c|c|c|c|c|}
\hline \multicolumn{5}{|c|}{ PRIVACY AND CONFIDENTIALITY } \\
\hline Disability policy core concepts & Constitutional principles & $\begin{array}{c}\begin{array}{c}\text { Federal statutory } \\
\text { sources }\end{array} \\
\end{array}$ & $\begin{array}{c}\text { Federal case law related to } \\
\text { statutes }\end{array}$ & Other relevant case law \\
\hline $\begin{array}{l}\text { Privacy and Confidentiality } \\
\text { Privacy refers to protection } \\
\text { against unwarranted } \\
\text { governmental interference in } \\
\text { decision-making that affects } \\
\text { private interests. The "zone" of a } \\
\text { person's or family's privacy } \\
\text { varies. Confidentiality refers to } \\
\text { information concerning one's } \\
\text { self or family; it includes the } \\
\text { person's or family's right to } \\
\text { access the information, rights of } \\
\text { correction and expungement, } \\
\text { and control over access to it by } \\
\text { others. }\end{array}$ & $\begin{array}{l}\text { Privacy rights protected by the } \\
1 \text { st and 14th Amendments }\end{array}$ & $\begin{array}{l}\text { Family Education Rights } \\
\text { and Privacy Act (FERPA; 1974, } \\
\text { 1998), } 20 \text { U.S.C. } § 1232 g- \\
\text { provides for parental (and } \\
\text { individual, when over the age } \\
\text { of majority) consent related to } \\
\text { control of records. FERPA is } \\
\text { incorporated into IDEA, } 20 \\
\text { U.S.C. } \$ \$ 1412(\text { a)(8) and } \\
\text { 1417(c). }\end{array}$ & & $\begin{array}{l}\text { Tarasoff v Regents, } 17 \text { Cal.3d } \\
425 \text { (1976)-therapists have a } \\
\text { duty to protect or warn when } \\
\text { there is a foreseeable danger } \\
\text { posed by one of their patients. } \\
\text { Washington v. Glucksberg, } 521 \\
\text { U.S. } 702 \text { (1997)- Washington's } \\
\text { ban on assisted suicide was } \\
\text { rationally related to a legitimate } \\
\text { government interest and did not } \\
\text { violate due process. } \\
\text { Vacco v. Quill, 521 U.S. } 793 \\
\text { (1997) - it is consistent with } \\
\text { the U.S. Constitution for New } \\
\text { York to treat assisted suicide and } \\
\text { the refusal of lifesaving treatment } \\
\text { differently. } \\
\text { Wyatt } v \text {. Stickney, } 325 \text { F Supp. } \\
781 \text { (M.D. Ala. 1971)-to } \\
\text { deprive any citizen of his or her } \\
\text { liberty upon the altruistic theory } \\
\text { that the confinement is for } \\
\text { humane, therapeutic reasons and } \\
\text { then fail to provide adequate } \\
\text { treatment violates the very } \\
\text { fundamentals of due process. }\end{array}$ \\
\hline
\end{tabular}


INTEGRATION

\begin{tabular}{|c|c|c|c|c|}
\hline Disability policy core concepts & Constitutional principles & Federal statutory sources & $\begin{array}{c}\begin{array}{c}\text { Federal case law related to } \\
\text { statutes }\end{array} \\
\end{array}$ & Other relevant case law \\
\hline $\begin{array}{l}\text { Integration } \\
\text { A person with a disability has } \\
\text { the right to not be segregated } \\
\text { solely on the basis of disability } \\
\text { from persons who do not have } \\
\text { disabilities and to not be barred } \\
\text { from participation in services } \\
\text { that serve persons who do not } \\
\text { have disabilities or to be limited } \\
\text { to participation in services that } \\
\text { serve only persons with } \\
\text { disabilities. The prohibition } \\
\text { against segregation includes a } \\
\text { mandate for integration into } \\
\text { generic or specialized services, or } \\
\text { both (as appropriate), and into } \\
\text { the most typical environments } \\
\text { (as appropriate). Sometimes the } \\
\text { right to integration depends on } \\
\text { and reflects the person's or } \\
\text { family's autonomy/choice. A } \\
\text { technique of integration is } \\
\text { inclusion. This term refers to the } \\
\text { placement or participation of a } \\
\text { person with a disability or their } \\
\text { family in generic services and } \\
\text { environments. (See also the core } \\
\text { concept of liberty.) }\end{array}$ & $\begin{array}{l}\text { "Integration" or "least restrictive/ } \\
\text { drastic environment/means"-as } \\
\text { grounded in the } 1 \mathrm{st}, 5 \text { th, 10th, } \\
\text { and } 14 \text { th Amendments. Also } \\
\text { grounded in antidiscrimination } \\
\text { laws. }\end{array}$ & $\begin{array}{l}\text { IDEA, } 20 \text { U.S.C. } \S 1412(\mathrm{a})(5)(\mathrm{A}) \\
\text { - authorizes inclusion of students } \\
\text { with disabilities into general } \\
\text { curriculum; } \S 1414(\mathrm{~d})(1)(\mathrm{A})(\mathrm{i}), \\
\text { (ii), (iii), and (iv)-sets out } \\
\text { provisions related to access to and } \\
\text { participation in the general } \\
\text { curriculum. } \\
\text { Title XIX (HCBSWaivers; P .L. } \\
\text { 92-223) of the Social Security } \\
\text { Act, } 42 \text { U.S.C. } \$ 1396 \text { n(b)- } \\
\text { provides funding to prevent } \\
\text { institutionalization or to move an } \\
\text { individual back into the } \\
\text { community from a non- } \\
\text { community setting; funds a class } \\
\text { of "habilitation services" to help } \\
\text { the person reside at home and in } \\
\text { the community. } \\
\text { Developmental Disabilities } \\
\text { Assistance \& Bill of Rights Act, } \\
42 \text { U.S.C. } \S 15001-\text { creates } \\
\text { national goal of inclusion (also, } \\
\text { productivity and independence). } \\
\text { ADA, } 42 \text { U.S.C. } \S \S 12101 \text { et seq.- } \\
\text { ensures inclusion through reasonable } \\
\text { accommodations to otherwise } \\
\text { qualified individuals. } \\
\text { Rehabilitation Act, } 29 \text { U.S.C. } \S \S \\
\text { 794 et seq.- same as ADA, but } \\
\text { applies only to federally assisted } \\
\text { programs. } \\
\text { Note. The child welfare, family } \\
\text { support, and adoption assistance } \\
\text { statutes (set out under the } \\
\text { category of family integrity and } \\
\text { unity) also advance inclusion in } \\
\text { community because membership } \\
\text { in a family is a means of } \\
\text { community membership. }\end{array}$ & $\begin{array}{l}\text { Sacramento City Unified } \\
\text { School Dist., Bd. of Educ. v. } \\
\text { Rachel H. By and Through } \\
\text { Holland, 14 EM } 1398 \text { (9th Cir. } \\
\text { (Cal.), 1994)-there are four } \\
\text { criteria for determining least } \\
\text { restrictive (most inclusive) } \\
\text { educational services for students } \\
\text { with disabilities. } \\
\text { Olmstead v. L.C., } 527 \text { U.S. } 581 \\
\text { (1999)-the ADA requires } \\
\text { states to provide community- } \\
\text { based placements in lieu of } \\
\text { institutionally based placements } \\
\text { (subject to three defenses) }\end{array}$ & $\begin{array}{l}\text { City of Cleburne v. Cleburne } \\
\text { Living Center, } 473 \text { U.S. } 432 \\
\text { (1985) discrimination in } \\
\text { community placement violated } \\
\text { equal protection doctrine. } \\
\text { Heller v. Doe, } 509 \text { U.S. } 312 \\
\text { (1993)-application of the least } \\
\text { restrictive alternative principle is } \\
\text { not mandatory in civil } \\
\text { commitment proceedings. }\end{array}$ \\
\hline
\end{tabular}


PRODUCTIVITY AND CONTRIBUTION

\begin{tabular}{|c|c|c|c|c|}
\hline Disability policy core concepts & Constitutional principles & Federal statutory sources & $\begin{array}{c}\text { Federal case law related to } \\
\text { statutes }\end{array}$ & Other relevant case law \\
\hline $\begin{array}{l}\text { Productivity and Contribution } \\
\text { Refers to engagement in income- } \\
\text { producing work or in unpaid } \\
\text { work that contributes to a } \\
\text { household or community. A } \\
\text { synonym for productivity is } \\
\text { economic self-sufficiency. }\end{array}$ & $\begin{array}{l}\text { Antidiscrimination and equal } \\
\text { protection. The constitutional } \\
\text { principles of antidis - } \\
\text { crimination and equal } \\
\text { protection do not themselves } \\
\text { explicitly support the core } \\
\text { concept of productivity and } \\
\text { contribution. Without these } \\
\text { principles, however, people } \\
\text { with dis abilities are } \\
\text { constrained in their } \\
\text { opportunities and abilities to } \\
\text { be productive and } \\
\text { contributory. These principles } \\
\text { thus are the means by which } \\
\text { the core concept is realized. }\end{array}$ & 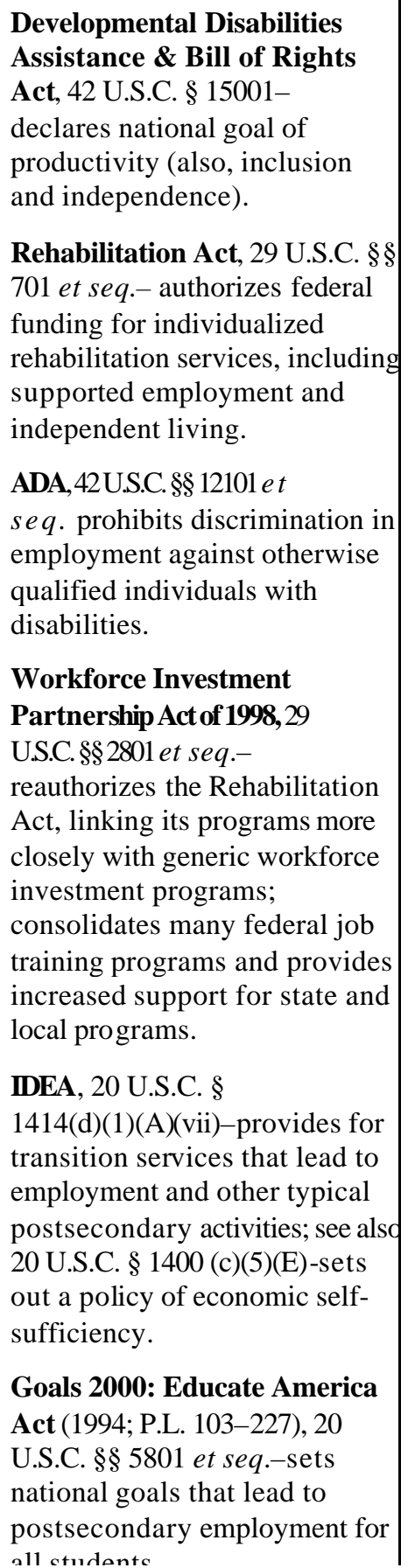 & & \\
\hline
\end{tabular}


PRODUCTIVITY AND CONTRIBUTION

\begin{tabular}{|c|c|c|c|c|}
\hline Disability policy core concepts & Constitutional principles & Federal statutory sources & $\begin{array}{c}\text { Federal case law related to } \\
\text { statutes }\end{array}$ & Other relevant caselaw \\
\hline & & 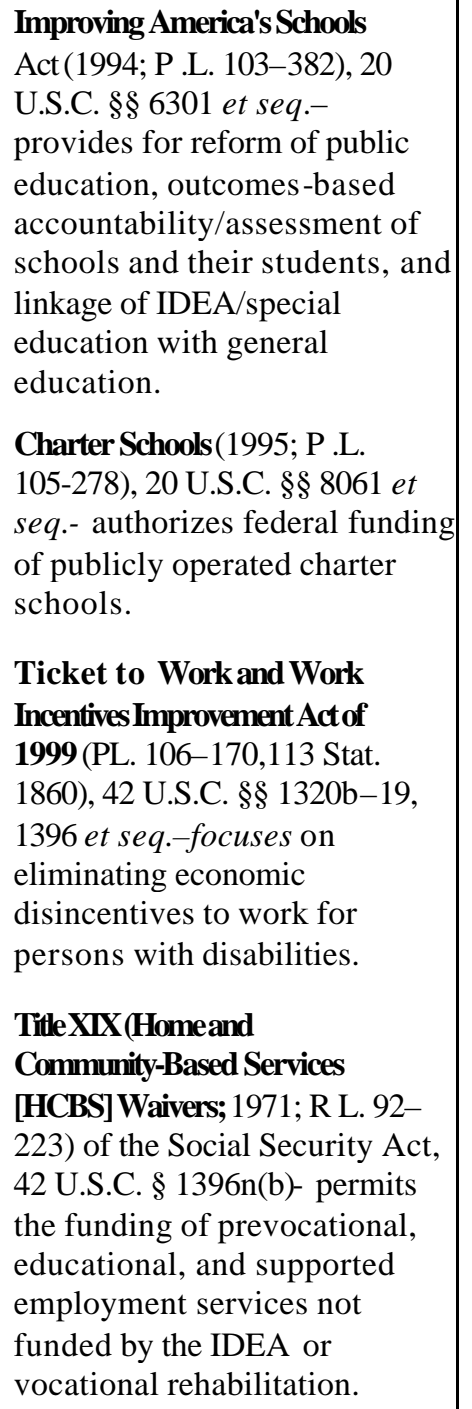 & & \\
\hline
\end{tabular}


FAMILY INTEGRITY AND UNITY

\begin{tabular}{|c|c|c|c|c|}
\hline Disability policy core concepts & Constitutional principles & Federal statutory sources & $\begin{array}{c}\begin{array}{c}\text { Federal case law related to } \\
\text { statutes }\end{array} \\
\end{array}$ & Other relevant case law \\
\hline $\begin{array}{l}\text { Family Integrity and Unity } \\
\text { Policy presumes in favor of } \\
\text { preserving and strengthening } \\
\text { the family as the core unit of } \\
\text { society. It recognizes the value } \\
\text { to individuals and society of a } \\
\text { "home." It is reflected in services }\end{array}$ & $\begin{array}{l}\text { The substantive due process } \\
\text { clauses of the } 5 \text { th and } 14 \text { th } \\
\text { Amendments recognize a } \\
\text { fundamental liberty interest of } \\
\text { parents in the care, custody, } \\
\text { and control of their children. }\end{array}$ & $\begin{array}{l}\text { Child Abuse Prevention and } \\
\text { Treatment and Adoption } \\
\text { Reform Act of 1978, } 42 \\
\text { U.S.C. § 5106a - provides } \\
\text { grants to states for } \\
\text { improvement of child } \\
\text { protective services programs; }\end{array}$ & & $\begin{array}{l}\text { Troxel v. Granville, } 530 \text { U.S. } \\
57 \text { (2000)-fundamental } \\
\text { liberty interests include } \\
\text { parents' rights to raise children } \\
\text { and to make decisions } \\
\text { concerning their care, custody, } \\
\text { and control. }\end{array}$ \\
\hline
\end{tabular}

that maintain the family intact;

includes provision for measures

such as prevention, treatment,

and research programs.

members; and respond to the

family based on its cultural,

ethnic, linguistic, or other

socioeconomic traits and choices

Related concepts are family

centeredness and cultural

\section{Adoption Assistance and}

Child Welfare Act, P 96-272,

42 U.S.C. $\$ \S 620$ et seq. (child

welfare services) \& $\S 670$ et

seq.(foster care and adoption

assis tance), as amended by

Adoption and Safe Families

Act, P .L. 105-89, 42 U.S.C. $\S \S$

629 et seq.-helps states

develop and expand family

support and family

preservation service programs.

Seealso Foster Care

Independence Act of 1999,

PL. 106-169,113 Stat.

1822- enhances transition

processes in leaving foster care

and entering adulthood.

Title XIX (HCBS Waivers) of the Social Security Act, 42

U.S.C. § 1396n(b)-enables

families to keep family

members at home and to avoid

placement into institutional

settings; waives some

restrictions against families

being reimbursed to provide

care.

\section{Lassiter v. Dept. of Social}

Services, 452 U.S. 18 (1981)-

refusal to appoint counsel for

indigent parent in a parental

status termination proceeding

does not violate the 14 th

Amendment due process

clause.

Santosky v. Kramer, 455 U.S

745 (1982)-before a state may

sever completely and

irrevocably the rights of parents in their natural child,

due process requires that the

state support its allegations by

at least clear and convincing

evidence.

Baltimore v. Bouknight, 493

U.S. 549 (1990)-a mother

may not invoke the 5 th

Amendment privilege against

self-incrimination to resist an order of the juvenile court to produce her abused child for evaluation.

Suter v. Artist M., 503 U.S.

347 (1992)-the Adoption Act

neither confirmed an

enforceable private right to

child protective or family

preservation services on its

beneficiaries nor created an

implied cause of action on their

behalf. 
FAMILY INTEGRITY AND UNITY

\begin{tabular}{|c|c|c|c|c|}
\hline Disability policy core concepts & Constitutional principles & Federal statutory sources & $\begin{array}{c}\text { Federal case law related to } \\
\text { statutes }\end{array}$ & Other relevant case law \\
\hline & & 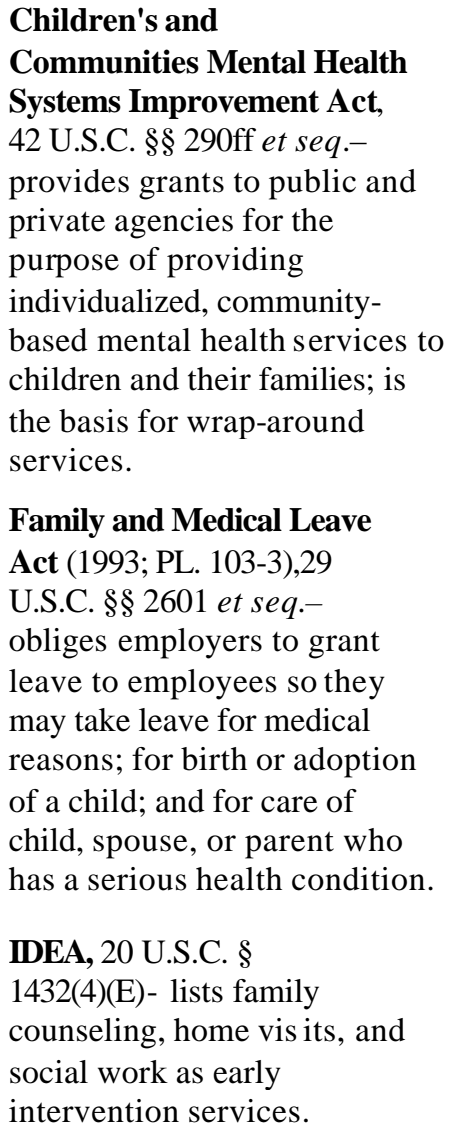 & & \\
\hline
\end{tabular}


FAMILY CENTEREDNESS: SERVICES TO WHOLE FAMILY

\begin{tabular}{|c|c|c|c|c|}
\hline $\begin{array}{c}\begin{array}{c}\text { Disability policy core } \\
\text { concepts }\end{array} \\
\end{array}$ & Constitutional principles & Federal statutory sources & $\begin{array}{c}\begin{array}{c}\text { Federal case law related to } \\
\text { statutes }\end{array} \\
\end{array}$ & Other relevant case law \\
\hline $\begin{array}{l}\text { Family-Centeredness: Services } \\
\text { to Whole Family } \\
\text { These services respond to the } \\
\text { needs of the entire family of a } \\
\text { person with a disability in an } \\
\text { individualized and appropriate } \\
\text { manner. They (a) support families } \\
\text { to raise their children with } \\
\text { disabilities in the family home, (b) } \\
\text { strengthen the role of the family as } \\
\text { the primary caregiver, (c) maintain } \\
\text { the family's intactness and unity, } \\
\text { and (d) reunite families with their } \\
\text { children who have been placed out } \\
\text { of the family home. }\end{array}$ & & $\begin{array}{l}\text { IDEA, } 20 \text { U.S.C. } \S \S 1436 \text { et } \\
\text { seq.(Part C)-authorizes } \\
\text { funding of services to families } \\
\text { of infants and toddlers (birth to } \\
\text { 3); } 20 \text { U.S.C. } § 1414(\text { d)- } \\
\text { provides for related services } \\
\text { that include services to a } \\
\text { student's family. } \\
\text { Title XIX (HCBS Waivers) of } \\
\text { the Social Security Act, } 42 \\
\text { U.S.C. } § 1396 \text { n(b)-enables } \\
\text { families to keep family } \\
\text { members at home as opposed } \\
\text { to institutional setting; waives } \\
\text { some restrictions against } \\
\text { families being reimbursed. } \\
\text { Supplemental Security } \\
\text { Income for the Aged, Blind, } \\
\text { \& Disabled of Title XVI of the } \\
\text { SocialSecurity Act, } 42 \text { U.S.C. } \\
\S \S 1381 \text { et seq.- provides } \\
\text { cash benefits to families who } \\
\text { meet federal poverty standards } \\
\text { and whose children have } \\
\text { severe disabilities. } \\
\text { Title V (Maternal and Child } \\
\text { Health Services Block Grant; } \\
\text { 1963; P.L. } 88-156 \text { ), } 42 \text { U.S.C. } \S \S \\
701-709-\text { authorizes grants to } \\
\text { states to increase access to } \\
\text { quality maternal and child } \\
\text { health services; to reduce the } \\
\text { incidence of preventable } \\
\text { childhood diseases and } \\
\text { disabilities; to increase } \\
\text { immunization rates; to expand } \\
\text { the availability of rehabilitative } \\
\text { services to blind and disabled } \\
\text { children; to minimize the } \\
\text { debilitating effects of }\end{array}$ & & \\
\hline
\end{tabular}


FAMILY CENTEREDNESS:SERVICES TO WHOLE FAMILY

\begin{tabular}{|c|c|c|c|c|}
\hline Disability policy core concepts & Constitutional principles & Federal statutory sources & $\begin{array}{c}\text { Federal case law related to } \\
\text { statutes }\end{array}$ & Other relevant case law \\
\hline & & $\begin{array}{l}\text { genetically linked conditions; to } \\
\text { promote family-centered, } \\
\text { community-based, coordinated } \\
\text { care for children with special } \\
\text { health-care needs and to } \\
\text { facilitate community-based } \\
\text { services for them and their } \\
\text { families. } \\
\text { Family and Medical Leave } \\
\text { Act, } 29 \text { U.S.C. } \$ \S 2601 \text { et seq.- } \\
\text { obliges employers to grant } \\
\text { leave to employees so they may } \\
\text { take leave for medical reasons; } \\
\text { for birth or adoption of a child; } \\
\text { and for care of a child, spouse, } \\
\text { or parent who has a serious } \\
\text { health condition. }\end{array}$ & & \\
\hline
\end{tabular}


CULTURAL RESPONSIVENESS

\begin{tabular}{|c|c|c|c|c|}
\hline Disability policy core concepts & Constitutional principles & Federal statutory sources & $\begin{array}{c}\begin{array}{c}\text { Federal case law related to } \\
\text { statutes }\end{array} \\
\end{array}$ & Other relevant case law \\
\hline $\begin{array}{l}\text { Cultural Responsiveness } \\
\text { These services respond to the } \\
\text { beliefs, values, interpersonal } \\
\text { styles, attitudes, cultural, } \\
\text { ethnic, linguis tic, or other } \\
\text { socioeconomic traits of the } \\
\text { person or family and thereby } \\
\text { have a great likelihood of } \\
\text { ensuring maximum } \\
\text { participation of and benefit to } \\
\text { the person or family. }\end{array}$ & $\begin{array}{l}\text { Under a theory of equal } \\
\text { protection, it is illegal to } \\
\text { discriminate solely on the basis } \\
\text { of a person's or family's ethnic, } \\
\text { linguistic, racial, or cultural } \\
\text { origins. }\end{array}$ & 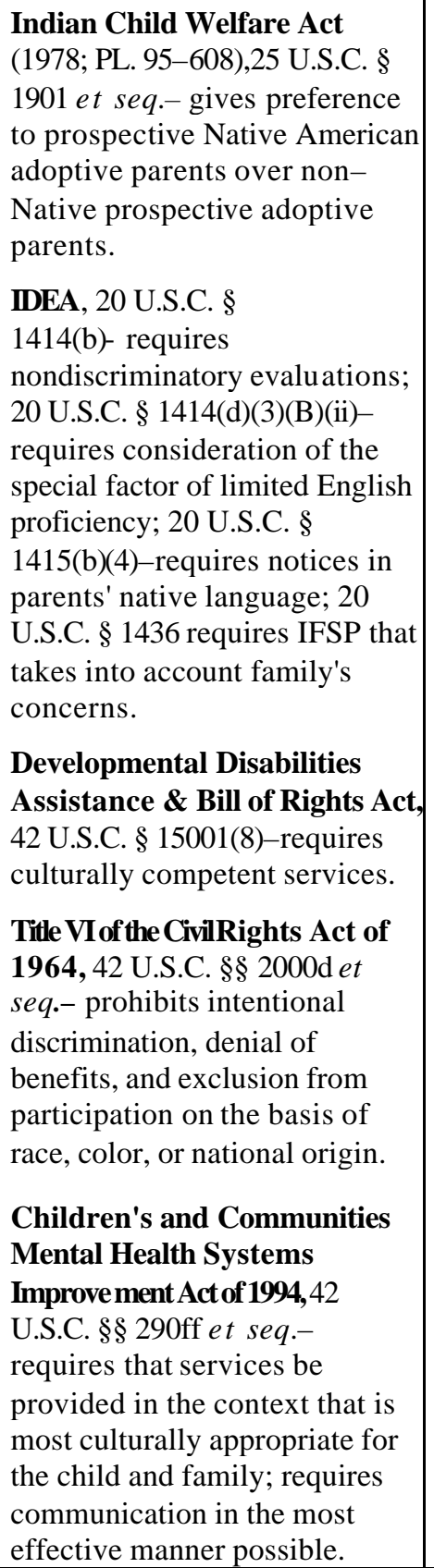 & $\begin{array}{l}\text { Mississippi Band of Choctaw } \\
\text { Indians } \text { v. Holyfield, } 490 \text { U.S. } \\
30 \text { (1989)-tribal juris diction } \\
\text { for purposes of the Indian } \\
\text { Child Welfare Act extends even } \\
\text { to Native American children } \\
\text { who have never been physically } \\
\text { present on a reservation. }\end{array}$ & $\begin{array}{l}\text { Lau v. Nichols, } 414 \text { U.S. } 563 \\
\text { (1974)-by failing to establish a } \\
\text { program to deal with the } \\
\text { complaining students' language } \\
\text { problem, a school district } \\
\text { violated the Civil Rights Act of } \\
\text { 1964. }\end{array}$ \\
\hline
\end{tabular}


Procedural due process under the 5th and 14th Amendments.

\section{IDEA, 20 U.S.C. \& 1415-}

provides for procedural (due process) safeguards, including notice, opportunity for mediation, administrative

hearing, and judicial review; 20 U.S.C. § 1416-authorizes withholding of federal funds.

ADA, 42 U.S.C. $\S 12101$ et seq.-provides for administrative and judicial remedies, including private cause of action, damages, and attorney fee recovery.

Rehabilitation Act, 29 U.S.C. $\S \S 794$ et seq.-provides adminis trative and judicial remedies similar to those of the ADA.
Federal case law related to statutes

Other relevant case law

Jackson v. Indiana, 406 U.S. 715 (1972)-a person's civil commitment violated the equal protection clause because he was subjected to a more lenient commitment standard and a more stringent standard of release and was committed solely on account of his incompetency to stand trial.

Addington v. Texas, 441 U.S 418(1979)-order of commitment was vacated and remanded for a determination of whether the proof of appellant's mental illness and dangerousness to himself and others could be proven by more than a preponderance of the evidence.

Parham v. J.R., 442U.S. 584 (1979)-for the commitment of minors by their parents, an independent review must be held (may be judicial or administrative).

Lassiter v. Dept of Social Services, 452 U.S. 18 (1981)refusal to appoint counsel for indigent parent in parental status termination proceeding did not violate the 14 th Amendment's due process clause.

Santosky v. Kramer, 455 U.S 745 (1982)-before a state may completely and irrevocably sever the rights of parents in their natural child, due process requires that the state support its allegations by at least clear and convincing evidence. 
ACCOUNTABILITY

\begin{tabular}{|c|c|c|c|c|}
\hline Disability policy core concepts & Constitutional principles & Federal statutory sources & $\begin{array}{c}\text { Federal case law related to } \\
\text { statutes }\end{array}$ & Other relevant case law \\
\hline & & & & $\begin{array}{l}\text { DeShaney } \text {. Winnebago, } 489 \text { U.S. } \\
189 \text { (1982)- } \$ 1983 \text { (civil rights) } \\
\text { liability does not attach in absence } \\
\text { of physical custody by the state. } \\
\text { Baltimore v. Bouknight, } 493 \text { U.S. } \\
549 \text { (1990)-a mother may not } \\
\text { invoke the 5th Amendment } \\
\text { privilege against self-incrimination } \\
\text { to resist an order of the juvenile } \\
\text { court to produce her abused child } \\
\text { for evaluation. } \\
\text { Heller v. Doe, } 509 \text { U.S. } 312 \text { (1993)- } \\
\text { application of the least restrictive } \\
\text { alternative principle is not } \\
\text { mandatory in civil commitment } \\
\text { proceedings. }\end{array}$ \\
\hline
\end{tabular}




\begin{tabular}{|c|c|c|c|c|}
\hline Disability policy core concepts & Constitutional principles & Federal statutory sources & $\begin{array}{c}\text { Federal case law related to } \\
\text { statutes }\end{array}$ & Other relevant case law \\
\hline $\begin{array}{l}\text { Professional and System } \\
\text { Capacity } \\
\text { A service system should have the } \\
\text { capacity to implement any one } \\
\text { or more concepts as appropriate } \\
\text { for that system. }\end{array}$ & $\begin{array}{l}\text { As is the case with the core } \\
\text { concept of prevention, there is } \\
\text { no dear constitutional right to } \\
\text { competent professional } \\
\text { intervention. There is, however, } \\
\text { a judicial doc trine that requires } \\
\text { courts to defer to the expertise } \\
\text { of professionals. Sometimes } \\
\text { called "the doctrine of } \\
\text { presumptive validity" } \\
\text { (professionals' decisions are } \\
\text { presumed to be valid) or } \\
\text { "judicial deference" (judges } \\
\text { should defer to professionals in } \\
\text { the areas of professionals' } \\
\text { competence), this doctrine } \\
\text { arguably advances the core } \\
\text { concept of professional } \\
\text { capacity: The doctrine is } \\
\text { insupportable if the } \\
\text { professionals themselves do not } \\
\text { have the capacity to make } \\
\text { professionally defensible } \\
\text { judgments (as required by such } \\
\text { Supreme Court cases as } \\
\text { Youngberg } v \text {. Romeo, } 457 \text { U.S. } \\
307 \text { (1982)). }\end{array}$ & $\begin{array}{l}\text { See all statutes identified } \\
\text { above. } \\
\text { IDEA, 20 U.S.C. Part B ( } \S \\
1412 \text { sets state eligibility } \\
\text { standards, } \S 1413 \text { sets local } \\
\text { eligibility standards, } \S 1414 \\
\text { explains student rights and } \\
\text { educators' response); Part C ( } \S \\
1435 \text { establishes statewide } \\
\text { system, } \S 1438 \text { regulates use of } \\
\text { funds); Part D ( } \S 1451 \text { et seq. } \\
\text { provides for nation-wide } \\
\text { improvement activities, } \\
\text { including State Program } \\
\text { Improvement grants). }\end{array}$ & & \\
\hline
\end{tabular}


PREVENTION AND AMELIORATION

\begin{tabular}{|c|c|c|c|c|}
\hline Disability policy core concepts & Constitutional principles & Federal statutory sources & $\begin{array}{c}\text { Federal case law related to } \\
\text { statutes }\end{array}$ & Other relevant case law \\
\hline $\begin{array}{l}\text { Prevention and } \\
\text { Amelioration } \\
\text { Prevention services seek } \\
\text { primary, secondary, and tertiary } \\
\text { prevention of disability. }\end{array}$ & $\begin{array}{l}\text { Strictly speaking, there is no } \\
\text { constitutional right to } \\
\text { government services in the } \\
\text { education, human and social } \\
\text { services, and health service- } \\
\text { delivery sectors. In } \\
\text { interpreting the Developmental } \\
\text { Disabilities Assistance and } \\
\text { Bill of Rights Act (42 U.S.C. } \\
\text { § } 15001 \text { et seq.), however, the } \\
\text { Supreme Court held, in } \\
\text { Youngberg } v \text {. Romeo ( } 457 \text { U.S. } \\
\text { 307 (1982)), that a person with } \\
\text { a developmental disability } \\
\text { who is in state custody (there, } \\
\text { institutionalized) has a right to } \\
\text { receive services to pre vent the } \\
\text { deterioration of the person's } \\
\text { pre-existing functioning } \\
\text { capacity. (See the core concept } \\
\text { of liberty for a different } \\
\text { reference to the Act and the } \\
\text { case.) Likewise, in DeShaney } v \text {. } \\
\text { Winnebago (489 U.S. } \\
\text { 189)(1989), the Court held that } \\
\text { when a person is in the } \\
\text { physical custody of the state, } \\
\text { the person has a right to be } \\
\text { protected from harm caused } \\
\text { by the state. (See the core } \\
\text { concept of protection from } \\
\text { harm). Arguably, the Romeo } \\
\text { approach (that there is an } \\
\text { constitutional right to certain } \\
\text { kinds of habilitative services) } \\
\text { and the DeShaney approach } \\
\text { (that there is a constitutional } \\
\text { right to be protected from } \\
\text { harm) support a theory, albeit } \\
\text { attenuated, that there is a } \\
\text { constitutional claim to } \\
\text { prevention. }\end{array}$ & $\begin{array}{l}\text { Title V (Maternal and } \\
\text { Child Health Services Block } \\
\text { Grant (1963; PL. 88-156), } 42 \\
\text { U.S.C. } § ~ 701-709- \\
\text { authorizes grants to states to } \\
\text { increase access to quality } \\
\text { maternal and child health } \\
\text { services; to reduce the } \\
\text { incidence of preventable } \\
\text { childhood diseases and } \\
\text { disabilities; to increase } \\
\text { immunization rates; to expand } \\
\text { the availability of } \\
\text { rehabilitative services to } \\
\text { children who are blind and } \\
\text { children with disabilities; to } \\
\text { minimize the debilitating } \\
\text { effects of genetically linked } \\
\text { conditions; to promote } \\
\text { family-centered, community- } \\
\text { based, coordinated care for } \\
\text { children with special health- } \\
\text { care needs, and to facilitate } \\
\text { community-based services for } \\
\text { them and their families. } \\
\text { Title XVIII (Medicare)(1965; } \\
\text { PL. } 89-97 \text { ), } 42 \text { U.S.C. } § \S 1395 \\
\text { et seq. funds a specific class } \\
\text { of health-care services for } \\
\text { elderly individuals and persons } \\
\text { with disabilities, with the } \\
\text { objective of preventing further } \\
\text { disability. } \\
\S \S 1396 \text { and } 1396 d \text { (Title XIX) } \\
\text { authorizes grants to states to } \\
\text { provide medical assistance } \\
\text { programs for families of } \\
\text { dependent children and for } \\
\text { individuals who are elderly, } \\
\text { blind, or disabled; requires }\end{array}$ & & \\
\hline
\end{tabular}


PREVENTION AND AMELIORATION

\begin{tabular}{|c|c|c|c|c|}
\hline \multicolumn{5}{|c|}{ MELIOR } \\
\hline Disability policy core concepts & Constitutional principles & Federal statutory sources & $\begin{array}{c}\text { Federal case law related to } \\
\text { statutes }\end{array}$ & Other relevant case law \\
\hline & & 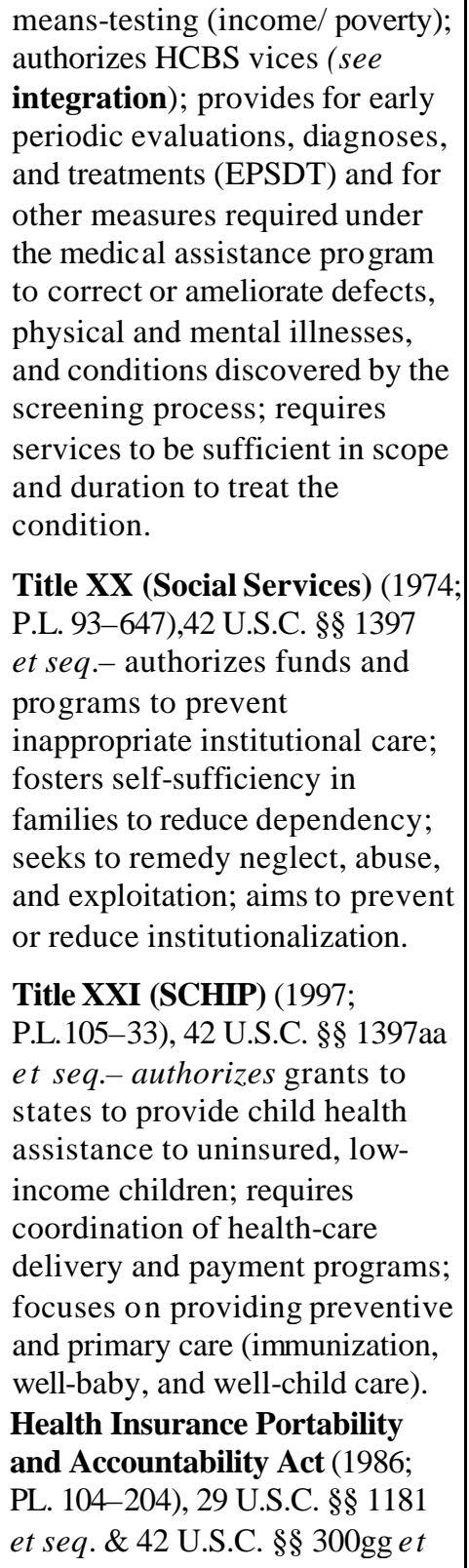 & & \\
\hline
\end{tabular}


PREVENTION AND AMELIORATION

\begin{tabular}{|c|c|c|c|c|}
\hline Disability policy core concepts & Constitutional principles & Federal statutory sources & $\begin{array}{c}\text { Federal case law related to } \\
\text { statutes }\end{array}$ & Other relevant case law \\
\hline & & 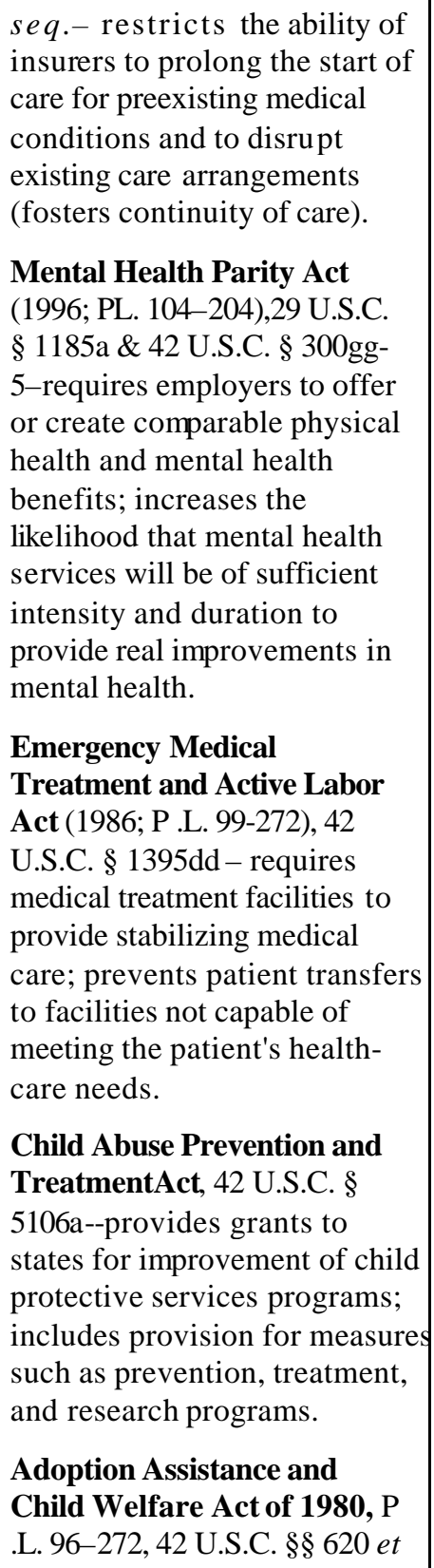 & & \\
\hline
\end{tabular}


PREVENTION AND AMELIORATION

\begin{tabular}{|c|c|c|c|c|}
\hline Disability policy core concepts & Constitutional principles & Federal statutory sources & $\begin{array}{c}\text { Federal case law related to } \\
\text { statutes }\end{array}$ & Other relevant case law \\
\hline & & $\begin{array}{l}\text { seq. (child welfare services) \& } \\
\S \S 670 \text { et seq (foster care and } \\
\text { adoption assis tance), as } \\
\text { amended by Adoption and } \\
\text { Safe Families Act (P L. 105- } \\
89), 42 \text { U.S.C. } \S \S 629 \text { et seq.- } \\
\text { helps states develop and expand } \\
\text { family support and family } \\
\text { preservation service programs } \\
\text { IDFA, 20U.S.C., Ch. } 33 \text {, Parts } \\
\text { B (20 U.S.C. } \S \S 1411 \text { et seq.) } \\
\text { establishes students' rights to } \\
\text { FAPE and C ( } 20 \text { U.S.C. } \S \S \\
1431 \text { et seq.) explains services } \\
\text { for infants and toddlers (B and } \\
\text { C as secondary or tertiary } \\
\text { prevention). }\end{array}$ & & \\
\hline
\end{tabular}

Note. The term services refers to the statutes authorizing various activities by government entities,
the services, and the entities' programs and operations (collectively, the service provider system). 